УДК 338.48

\title{
ОСОБЛИВОСТІ СТРАХУВАННЯ В СУЧАСНОМУ МІЖНАРОДНОМУ ТУРИСТИЧНОМУ БІЗНЕСІ
}

\section{FEATURES OF INSURANCE IN MODERN INTERNATIONAL TOURIST BUSINESS}

\author{
Кучай Оксана Василівна \\ кандидат економічних наук, доцент, \\ Київський національний лінгвістичний університет \\ ORCID: https://orcid.org/0000-0002-4201-7236
}

\author{
Kuchai Oksana \\ Kyiv National Linguistic University
}

\begin{abstract}
Стаття присвячена актуальним питанням страхування в сучасному міжнародному туристичному бізнесі. Здійснено теоретичне узагальнення основних засад розвитку ринку страхування в туристичній сфері. Систематизовано вітчизняну нормативно-правову базу страхування ризиків у сорері міжнародного туризму. Виділено ключові фрактори, які визнаються страховими чинниками у сфері туристичного бізнесу. Представлено структуру найбільш розповсюджених страхових випадків, які мали місце щодо громадян України, які перебували за кордоном в останні роки. Здійснено розподіл окремих країн з найбільшою часткою страхових випадків. Узагальнено найбільш популярні види страхування в міжнародному туризмі. Систематизовано особливості страхування в сучасному міжнародному туристичному бізнесі в умовах розгортання вірусної пандемії COVID-19 та окреслено напрями розвитку страхування туризму в умовах пост'COVIDної економіки.
\end{abstract}

Ключові слова: страхування, туризм, туристичний ринок, страхова діяльність, міжнародний туристичний бізнес.

Статья посвящена актуальным вопросам страхования в современном международном туристическом бизнесе. Осуществлено теоретическое обобщение основных принципов развития рынка страхования в туристической сорере. Систематизирована отечественная нормативно-правовая база страхования рисков в сорере международного туризма. Выделены ключевые фракторы, которые признаются страховыми фракторами в сорере туристического бизнеса. Представлена структура наиболее распространенных страховых случаев, которые имели место в отношении граждан Украины, которые находились за рубежом в последние годы. Осуществлено распределение отдельных стран с наибольшей долей страховых случаев. Обобщены наиболее популярные виды страхования в международном туризме. Систематизированы особенности страхования в современном международном туристическом бизнесе в условиях развертывания вирусной пандемии COVID-19 и обозначены направления развития страхования туризма в условиях пост'COVIDной экономики.

Ключевые слова: страхование, туризм, туристический рынок, страховая деятельность, международный туристический бизнес.

The article is devoted to topical issues of insurance in the modern international tourism business. Theoretical generalization of the basic principles of development of the insurance market in the tourist sphere is carried out. It is determined that insurance in the international tourism business should be considered as a system of financial and economic relations that arise between insurance companies, tourism entities and tourists to meet the interests and needs of each of them. It is generalized that insurance risk is the main object of insurance in tourism. At the same time, the insured event requires additional financial costs for the provision of various types of assistance and related services. The domestic regulatory framework for risk insurance in the field of international tourism is systematized. The key factors that are recognized as insurance factors in the field of tourism business: paid medical care in case of accidents, acute illnesses, cases of unforeseen disability, cases of loss of documents, luggage, unplanned expenses and other insured events that entail unforeseen and unintentional expenses insured tourists. The structure of the most common insurance cases that took place against Ukrainian citizens who have been abroad in recent years is presented. The distribution of individual countries with the largest share of insured events has been made. The most popular types of insurance in international tourism are generalized. The peculiarities of insurance in the modern international tourism business in the conditions of the COVID-19 viral pandemic are systematized and the directions of development of tourism insurance in the conditions of the post-COVID economy are outlined. It is proved that 
domestic insurers are in the phase of rethinking global trends in tourism insurance, one of the main areas of which should be considered to take into account the post-COVID period. Under these conditions, traditional insurers are now undergoing a major transformation of their own business models with a greater focus on the interests and needs of the insured, which will make this financial instrument more accessible to a new generation of customers. It is argued that the largest players in the industry need to strengthen regulatory mechanisms to ensure data confidentiality, advocate for cooperation between regulators at the global level and launch educational programs for the public to improve their insurance literacy.

Keywords: insurance, tourism, tourist market, insurance activity, international tourist business.

Постановка проблеми. На сучасному етапі розвитку міжнародного ринку послуг індустрія туризму, разом із задоволенням широкого кола потреб у подорожах та відпочинку становить певну небезпеку для життєдіяльності туристів. Це слід пов'язувати 3 тим, що в окремих країнах-центрах відвідування туристів обстановка може бути надзвичайно неспокійною. Різні фрорс-мажорні події, включаючи стихійні лиха, нещасні випадки, спалахи хвороб, недоліки у виробничо-господарський діяльності суб'єктів туристичної інсрраструктури здатні серйозно порушувати збалансовану діяльність туристичного комплексу, і відповідно, негативно впливати на якість відпочинку туристів.

Враховуючи сказане, важливим інструментом управління ризиками, який використовують туристичні підприємства для забезпечення власної стабільної діяльності та гарантування якісного відпочинку споживачам туристичних послуг слід вважати страхування. Саме страхування, як найважливіший елемент системи формування безпеки життєдіяльності в індустрії туризму сприяє мінімізації ризиків діяльності туристичних підприємств, а також безпеці міжнародних туристичних подорожей.

Враховуючи сказане, наукова проблематика дослідження особливостей страхування в сучасному міжнародному туристичному бізнесі $€$ надзвичайно актуальною та вимагає глибокого вивчення з метою зниження ризиків діяльності суб'єктів туристичної індустрії.

Аналіз останніх досліджень і публікацій. Наукова проблематика вивчення вітчизняного та міжнародного страхового ринку перебуває у центрі уваги таких відомих вчених, як: В. Базилевич, Н. Внукова, М. Шимінова, І. Стремковська, О. Заруба, С. Попович, Т. Гарматій, В Шахов, Л. Рейтман. Дослідження особливостей страхування ризиків у туристичній діяльності здійснювали наступні українські науковці: А. Крутик, Г. Михайличенко, А. Клімова, Н. Михайлова, В. Карцева, Н. Машина, О. Охріменко, О. Гаталяк, В. Стецький, Л. Шматько та ін. Водночас, незважаючи на існуючі фрахові розробки та досягнення з цієї проблеми, розвиток страхування діяльності у міжнародній туристичній індустрії потребує подальшого теоретичного опрацювання та розробки прикладних рекомендацій, адекватних сучасним тенденціям та реаліям.

Виділення невирішених раніше частин загальної проблеми. Особливої актуальності набуває проблематика страхування в сучасному міжнародному туристичному бізнесі в контексті розгортання вірусної пандемії COVID-19 у світі. Саме у 2020 р. вітчизняна туристична індустрія зіштовхнулася 3 глобальним викликом у своєму розвитку - важкою кризою, викликаною стрімким розповсюдженням нового виду коронавірусу COVID-19 по всій планеті. Відповідно, провідні країни-центри акумулювання туристичних потоків докладають надзвичайних зусиль у питаннях забезпечення безпечного, 3 точки зору, пост'COVIDного розвитку, відпочинку туристів, одним 3 головних напрямів якого слід вважати саме страхування ризиків, пов'язаних з вірусною хворобою.

Формулювання цілей статті. Метою роботи $€$ теоретичне узагальнення основних засад розвитку ринку страхування в туристичній ссрері, виявлення існуючих проблем функціонування суб'єктів туристичної діяльності у системі страхового забезпечення, а також ідентифрікація видів страхування в туризмі, які пропонуються в сучасних умовах пост'COVIDного розвитку.

Виклад основного матеріалу дослідження. Міжнародний туризм стрімко розвивається, поширюючись на всі країни світу, що породжує гостру проблему забезпечення безпеки туристів. Безпека туристів виражається через страхування.

Страхування - це відносини щодо захисту майнових інтересів фрізичних та юридичних осіб у разі настання певних подій за рахунок коштів, утворених із страхових внесків, які вони сплачують. Страхування туризму - це послуга, яка насамперед вигідна для клієнта. Страхові компанії та туристи у співпраці укладають договір. Виходячи $з$ цього, туристичне страхування належить до галузі цивільного права [1, с. 34]. 
На національному рівні державна політика у сорері страхування підлягає регулюванню. Обсяг правової та нормативної бази, що регулює страхові послуги, надзвичайно великий. Однак існує багато проблем, особливо в туристичній галузі, що призводять до необхідності удосконалення страхування в цій сорері.

Страхування туристів це ссрера страхування, де головною особою $є$ громадянин країни під час відпустки [3, с. 57]. Основним фрактором $€$ його захист під час туристичних подорожей. Одним із видів страхування $€$ страхування ризиків. Особисте туристичне страхування також $€$ ризикованим видом страхування. Характерною рисою особистого туристичного страхування може бути його короткостроковість. Ризик невизначеності щодо шкоди, яка може бути завдана у разі настання страхового випадку, також виявляється проблематичним. Під час страхування туристів взаємодіє велика кількість незалежних органів: туроператори (внутрішні та зовнішні), готелі, транспортні компанії, консульські служби тощо. Це збільшує ймовірність звернення до страхових компаній та настання страхових випадків. Важливе місце в цьому займає співпраця українських страхових компаній з іноземними [1; 2].

Туристи - це потенційні клієнти страхової організації. Це пов'язано з тим, що страховий ризик - це подія, яка не визначається часом, незалежно від волі туриста, небезпечна і тим самим створює стимул для страхування. Під час подорожі турист може зіткнутися 3 різними проблемами, тому він повинен бути впевнений, що йому буде надана своєчасна допомога на належному рівні. Це можуть бути проблеми, пов'язані 3 хворобами (алергія, отруєння, укуси отруйних тварин тощо), різними травмами, дорожньо-транспортними пригодами, аваріями, лавинами, зсувами в горах тощо.

Виходячи з цього, можна зробити висновок, що страховий ризик є основним об'єктом страхування в туризмі. Водночас, страховий випадок потребує додаткових орінансових витрат на надання різних видів допомоги та відповідних послуг. У такій ситуації на допомогу туристам приходить страхування, яке пропонує ряд послуг, що захищають сучасного мандрівника від різних ризиків [13].

Страхування ризиків у сорері туризму в нашій країні регулюється Законом України «Про страхування» від 07 березня 1996 року № 85/96-ВР [11] та Законом України «Про туризм» від 15 вересня 1995 року № 324/95-ВР [12].
Відповідно до ст. 1 Закону України «Про страхування» від 07 березня 1996 року «Страхування - це вид цивільно-правових відносин щодо захисту майнових інтересів фрізичних осіб та юридичних осіб у разі настання певних подій (страхових випадків), визначених договором страхування або чинним законодавством, за рахунок грошових фрондів, що фрормуються шляхом сплати фрізичними особами та юридичними особами страхових платежів (страхових внесків, страхових премій) та доходів від розміщення коштів цих фрондів» [11].

Водночас, ст. 1 Закону України «Про туризм» від 15 вересня 1995 року регулюються питання страхування туристів при здійсненні туристичних поїздок. Зокрема, у цьому нормативно-правовому акті зазначається, що «страхування туристів (медичне та від нещасного випадку) $€$ обов'язковим і забезпечується суб'єктами туристичної діяльності на основі угод із страховиками. Туристи вправі самостійно укладати договори на таке страхування. У цьому випадку вони зобов'язані завчасно підтвердити туроператору чи турагенту наявність належним чином укладеного договору страхування» [12].

Існує ряд фракторів, які визнаються страховими чинниками у ссрері туристичного бізнесу [3; 13]: платна медична допомога у разі нещасних випадків, гострих захворювань, випадків непередбаченої інвалідності, випадки втрати документів, багажу, випадки незапланованих витрат та інші страхові випадки, які тягнуть за собою непередбачені та ненавмисні витрати застрахованих туристів.

Виходячи $з$ цього, можна сказати, що охорона майна туристів у разі настання страхового випадку безпосередньо пов'язана зі страхуванням туриста. Крім того, це допомагає уникнути значних фрінансових витрат.

Дослідження страхових випадків, які мали місце щодо громадян України, які перебували за кордоном у 2018 та 2019 роках, проводив Аналітичний центр «Альфа Страхування» [7]. Було складено рейтинг найпоширеніших ризиків, який представлений на рис. 1.

Як видно з даних рис. 1, застудні захворювання становлять близько 40\% страхових випадків під час туристичного відпочинку за кордоном. Застуда - наслідок необережності самих туристів та відпочиваючих, оскільки вони пов'язані 3 тривалим перебуванням на сонці або в морозі. Також поширені різні види травм. Вони виникають при необережності українських туристів, які віддають перевагу активному відпочинку та туризму: відвід- 


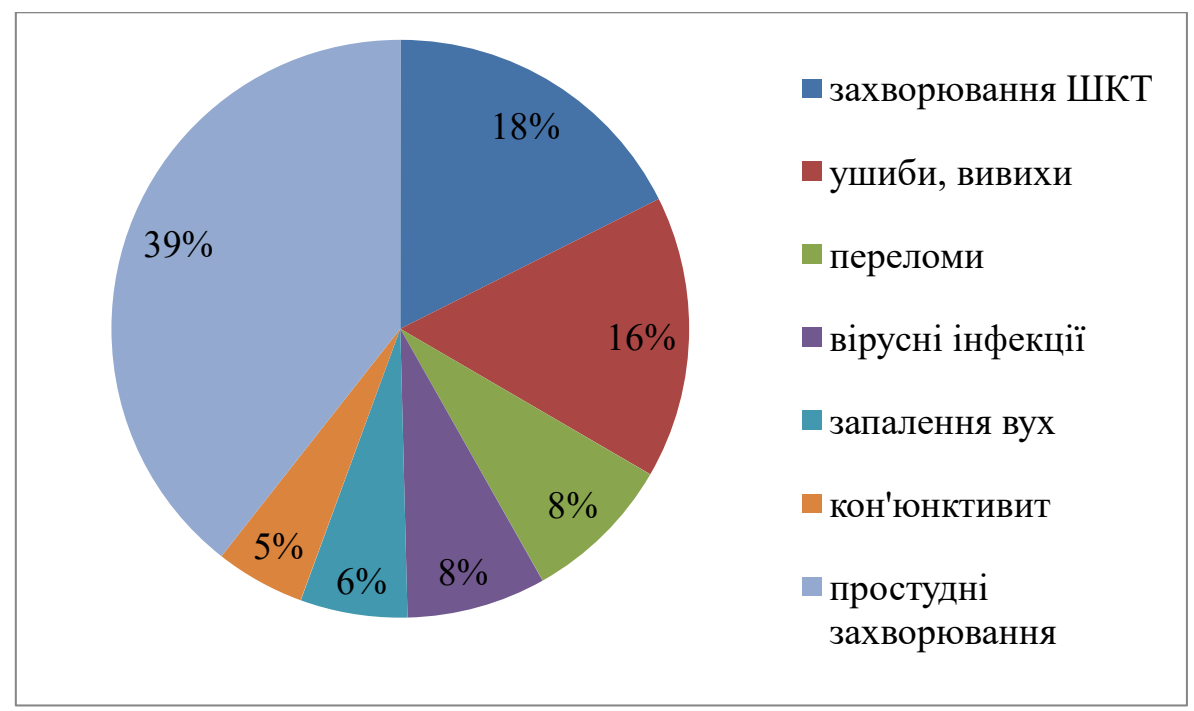

Рис. 1. Структура найбільш розповсюджених страхових випадків, які мали місце щодо громадян України, які перебували за кордоном у 2018 та 2019 роках, \%

Джерело: [7]

уванню аквапарків, серфінгу, дайвінгу, спелеотуризму, альпінізму тощо. Наприклад, у Болгарії та Німеччині травми, отримані внаслідок розтягування та вивиху, у 1,7 рази перевищують середньосвітові показники. На них припадає 20\% та 19\% страхових випадків відповідно. Також у Болгарії високий рівень захворювань шлунково-кишкового тракту. Він перевищує середньосвітові показники в 2,4 рази (23\% від загальної частки). Розглянемо частку інших країн: Індії - у 2,1 рази $(20,2 \%)$, Греції - у 1,5 рази $(18,3 \%)$, Індонезії та Кіпру - у 1,3 рази (12,5\%). У європейських країнах цей відсоток значно нижчий [7].

Вище описано найчастіші страхові випадки, водночас, на додаток до них можна виділити такі випадки, як судинні захворювання (інсраркти та інсульти). Вони можуть бути викликані літньою спекою і задухою, акліматизацією туристів. Загалом на ці захворювання припадає до 2,3\% від їх загальної кількості. У субтропічних країнах часті укуси комах та змій, їх часта становить $1,7 \%$, різні шкірні захворювання та алергічні реакції - 1,3\% [7].

Згідно з проведеним дослідженням, можна побачити, що Туреччина та Єгипет є найбільш ризикованими за статистикою, тому при складанні СК «Альсра Страхування» рейтингу країн, з найбільшою кількістю страхових випадків, представлених на рис. 2, їх не було взято до уваги.

Так, за винятком Туреччини та Єгипту, Таїланд очолює список країн за кількістю туристів, які звернулися за медичною допомогою.
Страхові випадки становлять тут 19,3\%, далі у списку - Кіпр - 13,5\%, Греція - 10\%, Болгарія - 8,4\%, Німеччина - 8,1\%, Індія - 6,9\%, Іспанія - 6,5\%, Чехія - 5,3\%, Австрія - 4\%, В'єтнам - 4\%.

Водночас, мандрівник не повинен забувати, що страховий випадок передбачений договором страхування, і він зобов'язаний здійснити страхову виплату страховій компанії. Таким чином, готуючись до подорожі, туристу, оформляючи страховий поліс, необхідно звернути увагу на те, які страхові ризики будуть покриватись страховою компанією [2, с. 22].

Страхові компанії України пропонують кілька основних видів туристичного страхування та реалізують комплексний особистий та майновий страховий захист туристів в ході здійснення подорожей, як в межах України так і за кордон. До комплексних програм страхування включаються, як обов'язкові для туристів види страхування, що регламентуються вимогами Закону України «Про туризм» [12], так й інші види страхування. Основою вибору конкретного «страхового продукту» споживачами туристичних послуг $€$ намагання уникнення додаткових витрат й фрінансових збитків у разі настання непередбачених ситуацій під час здійснення туристичних подорожей.

Найбільш популярні види страхування в міжнародному туризмі представлені на рис. 3.

Таким чином, туристичне страхування в Україні пропонує широкий спектр послуг, необхідних для успішного розвитку міжнародної індустрії туризму. 


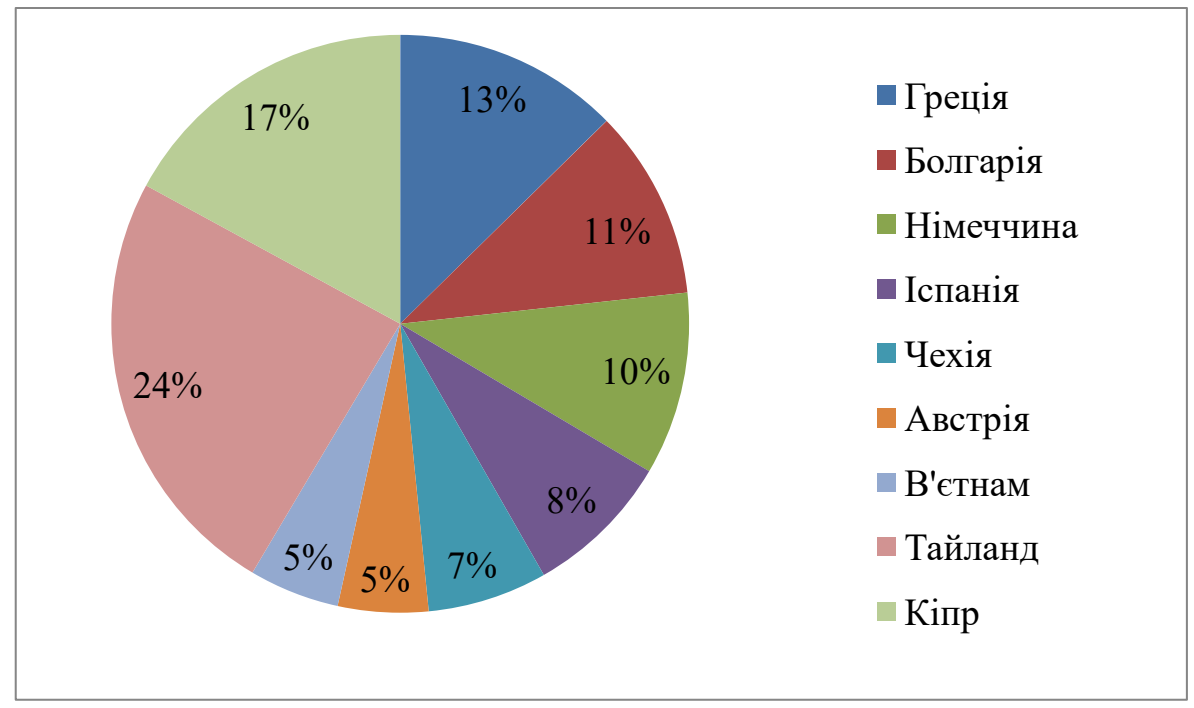

Рис. 2. Розподіл окремих країн з найбільшою часткою страхових випадків, \%

Джерело: [7]

Аналіз ринку міжнародного туристичного страхування відзначається як позитивними, так і негативними тенденціями. Так, за результатами дослідження Ліги страхових організацій України, у останні роки відбувається зростання страхової культури в середовищі споживачів туристичних послуг.
Також, покращилася асистанс-допомога туристам у європейських країнах. Заслуговує особливої уваги нова тенденція на ринку туристичного страхування, а саме страхування через Інтернет, яка набула особливого розвитку під час розгортання вірусної пандемії COVID-19. Онлайн-страхування в Україні

\begin{tabular}{|c|c|}
\hline \multicolumn{2}{|c|}{ Види страхування, поширені на ринку міжнародного туризму України } \\
\hline Обов'язкове & $\begin{array}{|lll|}\text { - страхування від нещасних випадків; } & \\
\text { - медичне страхування; } & \\
\text { - страхування цивільної } \quad \text { відповідальності } & \text { власників } \\
\text { транспортних засобів. } & & \\
\end{array}$ \\
\hline Добровільне & $\begin{array}{l}\text { - майнове страхування; } \\
\text { - страхування цивільної відповідальності за збитки, заподіяні } \\
\text { майну інших осіб; } \\
\text { - комплексне страхування ділових подорожей; } \\
\text { - страхування відповідальності агентів з продажу авіаційних } \\
\text { пасажирських перевезень; } \\
\text { - страхування відповідальності туроператора; } \\
\text { - страхування банківських гарантій; } \\
\text { - страхування на випадок затримки транспорту; } \\
\text { - страхування від ненадання або неповного надання } \\
\text { туристичних послуг; } \\
\text { - страхування на випадок неможливості здійснити подорож з } \\
\text { поважних причин; } \\
\text { - страхування на випадок передчасного повернення до місця } \\
\text { постійного проживання; } \\
\text { - страхування на покриття витрат, пов'язаних з лікуванням в } \\
\text { разі захворювання на СOVID-19. }\end{array}$ \\
\hline
\end{tabular}

Рис. 3. Види страхування, поширені на ринку міжнародного туризму України Джерело: [1; 3; 13] 
пропонують відомі страхові компанії «ТАС» [9], «Європейське туристичне страхування» [8], «Універсальна» [10] та «Альсра Страхування» [7]. Водночас, частка онлайн-страхування подорожей залишається досить низькою, а саме на рівні 5\% через законодавчі обмеження.

Спостереження фрахівців найбільших страхових компаній показують, що за останні роки збільшилася кількість поїздок пенсіонерів, які переважно обирають дешеві поїздки в Європу [5]. Страхові компанії оцінюють захист людей у цій віковій категорії значно дорожче, ніж зазвичай. Крім того, зростає попит на додаткове страхування, таке як додаткове медичне страхування, страхування багажу та інвалідність під час подорожей. Всі ці фрактори дуже взаємозалежні і разом збільшують вартість туру на $2-5 \%$.

Однак, незважаючи на деякі позитивні тенденції на міжнародному ринку страхових послуг у туристичному бізнесі, сучасні реалії вимагають вдосконалення механізму страхування в міжнародному туризмі. Досвід показує, що кількість туристів, які не можуть отримати медичну допомогу за кордоном, зростає, оскільки договори страхування укладаються таким чином, що значна частина ризиків, яким можуть бути схильні споживачі під час подорожі, не покривається. Багато ризикованих подій не зазначені у договорах страхування або пов'язані з форс-мажорними обставинами, які не завжди відшкодовуються страховиками. Причина цієї проблеми очевидна - низькі страхові тарифри для туристів, які подорожують за кордон. Так, в середньому обов'язковий страховий тарифр для туриста в будь-якій країні Європи становить 15-20 грн на добу [4].

Не менш глобальною проблемою $є$ нездатність представників туристичних компаній пояснити туристу механізм дії страхового полісу; неадекватна страхова культура споживачів туристичних послуг, які укладають договір страхування в поєднанні з туристичними ваучерами, тоді як туристичні компанії пропонують недороге страхування з мінімальними ризиками для зменшення оріксованих витрат; несвоєчасне надання інорормації про страхувальника страховій компанії; борг перед страховиками через банкрутство туристичних агентів.

Крім того, масовий розвиток туристичного бізнесу та сильна конкуренція на страховому ринку збільшують кількість шахрайств зі страхуванням споживачів. Найчастіше шахрайство проявляється у продажу страхо- вих полісів через Інтернет без ліцензії на цей вид діяльності; навіть при купівлі так званої «зеленої карти». Близько 10-30\% підроблених «зелених карт» продається саме на страховому ринку України [5].

Основними причинами масового розвитку страхових шахрайств у туристичному секторі $\epsilon$ корупція, відсутність механізмів регулювання та законодавчого регулювання страхових компаній щодо запобігання страховій злочинності. У більшості країн страхове шахрайство включено до кримінального законодавства, як окреме правопорушення. Ця практика поширена в Австрії, Німеччині, Польщі та Китаї. У США відповідальність за страхове шахрайство регулюється на державному рівні [4]. Однак, Україна не має чіткої правової бази в цій ссрері.

На початку 2020 року всі країни постраждали від пандемії коронавірусу нового типу, COVID-19, яка була оголошена Всесвітньою організацією охорони здоров'я. Вірус, перший спалах якого був зареєстрований у китайському м. Ухань наприкінці 2019 року, поширився на всі країни та континенти. Кордони країн були закриті, авіа- та залізничне сполучення припинено, а в багатьох містах запроваджено режим загальної самоізоляції. Варто зазначити, що людство не вперше стикається 3 пандемією, тоді як арсенал засобів боротьби з вірусами раніше був значно меншим. Принциповою відмінністю нинішньої пандемії $€$ одночасне виникнення так званої «неінсрекційної пандемії» («пандемічний страх»), яка пов'язана зі стрімким розвитком інформаційних технологій та негайним розповсюдженням інорормації в сучасному світі [2, с. 30].

Поточна ситуація має величезний вплив на всі сорери світової економіки, включаючи туризм. Як майже одностайно стверджують експерти, такої кризи в туризмі не спостерігалося з часів Другої світової війни. Зараз COVID-19 офріційно $€$ пандемією з безпрецедентними наслідками. Тому наслідки коронавірусу матимуть далекосяжні наслідки для здоров'я, безпеки та макроекономічного розвитку світової економіки в найближчі роки.

Водночас, інфрормація, яка надається страховиками про коронавірус, $є$ обнадійливою 3 огляду на нинішні екстремальні обставини. Криза COVID-19 є кредитним ризиком для страхового сектору і буде особливо проблематичною для страховиків без відповідних програм управління ризикам, в тому числі і у сорері міжнародного туризму. Страховики можуть зіткнутися 3 потенційними регулятор- 
ними та юридичними ризиками, якщо буде прийнято ретроактивне законодавство, щоб забезпечити покриття, пов'язане з коронавірусом. I хоча COVID-19 має багато негативних наслідків, експерти вважають, що багато страховиків можуть подолати кризу, продовжуючи обслуговувати своїх клієнтів, кредиторів та контрагентів в сорері міжнародного туризму [2, с. 30].

Глобальне туристичне страхування для іноземних туристів (головним чином, включаючи медичні витрати, скасування поїздок, затримки поїздок, втрату роботи) може призвести до значного збільшення вимог, у поєднанні $з$ масовим скороченням нових договорів страхування. Цей сектор відчуває труднощі та десріцит бюджету протягом тривалого часу через зменшення кількості мандрівників по всьому світу. Однак у майбутньому частка туристів, які обиратимуть туристичне страхування, зокрема щодо покриття витрат, пов'язаних з лікуванням в разі захворювання на COVID-19 зросте.

Отже, пандемія COVID-19 як для страхових компаній, так і для споживачів - це абсолютно нова ситуація, яка порівнюється 3 глобальними кризовими потрясіннями, що відбуваються раз на сто років. Так, наприклад, якщо у лютому 2020 року страхова компанія «Альфра Страхування» мала страхових премій у розмірі 20-25 млн грн на місяць, то вже в травні 500 тис. грн, тобто можна уявити усю складність ситуації [7]. Проте, завдяки достатній стабільності компанії була сформована міцна фрінансова подушка, яка гарантувала СК «Альсра Страхування» можливість працювати «в нуль» від восьми до дев'яти місяців і залишатися в бізнесі. Ті ж страхові компанії, які не змогли витримати такого фрінансового навантаження, змушені були вийти з ринку.

В умовах розгортання вірусної пандемії COVID-19 страхові компанії побачили, що багато туристів залишаються за кордоном і не можуть повернутися, тому що кордони були закриті, а їхні страхові поліси вже закінчилася. В цьому випадку страхові компанії дотримувались чітких правил, які зазначають: «Ми не страхуємо нікого, хто перебуває за кордоном, оскільки існує високий страховий ризик від реалізації страхового випадку» [6]. Наприклад, людина вже хворіє і за годину отримує страховий поліс. Оскільки це онлайнпродаж, згідно з правилами страховиків, вони мають право відмовитися від виплат за страховим випадками. У цій ситуації до провідних страхових компаній, зокрема, «Європейське туристичне страхування», «Універсальна», «Альфа Страхування» звернулося Міністерство закордонних справ України 3 проханням дозволити страхування туристам, які не можуть в"їхати в Україну. Пішовши на поступки, керівництво вищеозначених страховиків дало свою згоду, а інорормація щодо оновлених умов отримання страхових виплат з'явилася на відповідних веб-сайтах. Водночас, за даними моніторингу, було отримано інорормацію, що страхові премії почали зростати, тобто з'явилась тенденція до змін у бізнесі на краще.

Також, відбулися певні зміни, безпосередньо, в умовах страхування на період пост'COVIDного розвитку та адаптації. Отже, провідні страхові компанії, зокрема, «ARXстрахування» [6] та «Альсра Страхування» [7] заявили, що не будуть страхувати лікування COVID-19 у лікарнях більше 14 днів. Як правило, якщо турист поїхав на відпочинок і в нього на сьомий день був діагностований COVID-19, знадобиться максимум 14 днів, щоб вийти з цього стану. За таких умов, страхова компанія страхує до кінця туру плюс 15 днів після закінчення туру у випадку діагнозу COVID-19.

Щодо страхування медичних витрат, то провідні страхові компанії включили до умов страхування покриття витрат на експрестестування та лабораторні дослідження на COVID-19, а також амбулаторне та стаціонарне лікування застрахованої особи, яка захворіла на COVID-19, без зміни вартості страхового полісу. За таких умов, вартість медичного страхування становить 0,4-0,7 доларів на день [5].

Дослідження засвідчили, що відбулися певні зміни у страхуванні фрінансових ризиків, пов'язаних із скасуванням подорожі або перериванням поїздки, де були, також, враховані ризики, пов'язані з COVID-19, а саме, додали перелік випадків, які можуть бути причинами скасування подорожі або перебування туриста у місці відпочинку, хвороба застрахованої особи вірусом COVID-19, відмова від в'їзду в країну призначення через підозру органів влади країни подорожі, що застрахована особа страждає на хворобу COVID-19. Спочатку, у липні 2020 року, результати цих страхових виплат були позитивними через поодинокі випадки виплат. Однак, коли в листопаді-грудні почалася перша хвиля коронавірусу, стало зрозуміло, що за ціну, яку пропонували страхові компанії (в середньому 1,5 долара в день), не можливо покрити страхові витрати. 3 ура- 
хуванням цього, середня ціна була збільшена до 2-2,5\% вартості туру, якщо страхування від COVID-19 включено до кожного полісу, і до 7\%, якщо він купується фракультативно. Таким чином, стало зрозумілим, що в нинішній ситуації пандемічний страховий продукт не може бути дешевим [9; 10].

Перелік існуючих та потенційних загроз можна продовжувати, проте доводиться констатувати, що пандемія - це також можливість для страховиків зміцнити свої позиції на ринку. У сучасних реаліях, коли надходження страхових премій по страхуванню життя можуть значно скоротитись, технологічні досягнення особливо важливі при розробці нових інструментів надання страхових послуг, а також більш комплексних способів збору інфрормації. Нині настав той час, коли страховикам необхідно інтегрувати технології та бізнес, а також онлайн- та офлайн канали. Вже деякий час страховики впроваджують у свою роботу блокчейн, штучний інтелект, Інтернет речей, великі дані, доповнену реальність та хмарні технології.

Яскравим прикладом цього є страхові компанії, які зазвичай пропонують свої послуги лише через Інтернет. Сектор інноваційних онлайн-послуг у страховому секторі почав динамічно розвиватися близько восьми років тому, проте сьогодні «Inshurtech» $€$ однією 3 найбільших глобальних інноваційних екосистем. У 2019 році загальний обсяг фрінансування галузі досяг 6,9 млрд. Доларів США, що майже в 19 разів більше, ніж у 2012 році [4]. Лабораторії Іншуртех були створені та успішно фрункціонують у багатьох країнах, включаючи Україну. Вони стають більш доступними для учасників ринку страхування та дають можливість відбирати перспективні ідеї та брати безпосередню участь у їх реалізації.

Висновки. За результатами проведеного дослідження можна стверджувати, що страхування в міжнародному туристичному бізнесі слід розглядати, як систему фрінансово-економічних відносин, які виникають між страховими компаніями, суб'єктами туристичної сорери та туристами з приводу задоволення інтересів і потреб кожного з них. Можна стверджувати, що вітчизняні страховики перебувають у фразі переосмислення глобальних тенденцій розвитку страхування туризму, одним з головних напрямів якого слід вважати врахування пост'COVIDного періоду. За таких умов, традиційні страховики зараз переживають серйозну трансформацію власних бізнес-моделей з більшою орієнтацією на інтереси та потреби страхувальника, що робитиме цей фрінансовий інструмент більш доступним для нового покоління клієнтів. Звичайно, найбільшим гравцям галузі необхідно зміцнити регуляторні механізми для забезпечення конфріденційності даних, виступати за співпрацю між регуляторними органами на глобальному рівні та запускати освітні програми для громадськості 3 метою підвищення їхньої страхової грамотності. Цей шлях оновлення у страховій галузі, як і в будь-якій іншій сорері діяльності, буде непростим, що визначає необхідність подальших досліджень за даним напрямом.

\section{СПИСОК ВИКОРИСТАНИХ ДЖЕРЕЛ:}

1. Гаталяк О.М., Стецький В.В. Страхування у туризмі : навч. посібн. Львів : ЛНУ ім. І. Франка, 2020. 114 с.

2. Михайличенко Г., Клімова А. Світовий туристичний ринок: транссрормації після пандемії. Зовнішня торгівля: економіка, фрінанси, право. 2020. № 2. С. 21-37.

3. Михайлова Н.В., Карцева В.В. Особливості страхування відповідальності в туристичному бізнесі. Науковий вісник МдУ імені В.О. Сухомлинського. 2014. Випуск 5.2(101). С. 57-60.

4. Офіційний веб-сайт Всесвітньої туристської організації. URL: https://www.unwto.org/ru

5. Офіційний веб-сайт Ліги страхових організацій України. URL: http://uainsur.com

6. Ооріційний веб-сайт CK «ARX-страхування». URL: https://arx.com.ua/

7. Офріційний веб-сайт СК «Альфра Страхування». URL: https://alfaic.ua/

8. Офріційний веб-сайт СК «Європейське туристичне страхування». URL: https://eurotravelins.com.ua

9. Офріційний веб-сайт CK «TAC». URL: https://sgtas.ua/

10. Офріційний веб-сайт СК «Універсальна». URL: https://universalna.com/ru/

11. Про страхування : Закон України від 07 березня 1996 року № 85/96-ВР (редакція від 01.08.2021, підстава - 1591-IX). URL: https://zakon.rada.gov.ua/laws/show/85/96-вр\#Text

12. Про туризм : Закон України від 15 вересня 1995 року № 324/95-ВР (редакція від 16.10.2020, підстава 124-IX). URL: https://zakon.rada.gov.ua/laws/show/324/95-вp\#Text

13. Ярош В.В. Перспективи розвитку страхування туристів в Україні. URL: https://conf.ztu.edu.ua/wp-content/ uploads/2021/01/319.pdf 


\section{REFERENCES:}

1. Hatalyak O.M., Stetskyy V.V. (2020) Strakhuvannya u turyzmi: navch. posibn. [Insurance in tourism: textbook]. Lviv: LNU im. I. Franka, 114 p.

2. Mykhaylychenko H., Klimova A. (2020) Svitovyy turystychnyy rynok: transformatsiyi pislya pandemiyi [World tourism market: transformations after the pandemic]. Zovnishnya torhivlya: ekonomika, finansy, pravo, 2, 21-37.

3. Mykhaylova N.V., Kartseva V.V. (2014) Osoblyvosti strakhuvannya vidpovidalnosti v turystychnomu biznesi. [Features of liability insurance in the tourism business]. Naukovyy visnyk MDU imeni V.O. Sukhomlynskoho, 5.2(101), 57-60.

4. Ofitsiynyy veb-sayt Vsesvitnoyi turyst-skoyi orhanizatsiyi [Official website of the World Tourism Organization]. Available at: https://www.unwto.org/ru

5. Ofitsiynyy veb-sayt Lihy strakhovykh orhanizatsiy Ukrayiny [Official website of the League of Insurance Organizations of Ukraine]. Available at: http://uainsur.com

6. Ofitsiynyy veb-sayt SK «ARX-strakhuvannya» [Official website of ARX-Insurance Insurance Company]. Available at: https://arx.com.ua/

7. Ofitsiynyy veb-sayt SK «Alfa Strakhuvannya» [Official website of Alfa Insurance Insurance Company]. Available at: https://alfaic.ua/

8. Ofitsiynyy veb-sayt SK «Yevropeyske turystychne strakhuvannya» [Official website of the European Travel Insurance Company]. Available at: https://eurotravelins.com.ua

9. Ofitsiynyy veb-sayt SK «TAS» [Official website of TAS Insurance Company]. Available at: https://sgtas.ua/

10. Ofitsiynyy veb-sayt SK «Universalna» [Official website of Universalna Insurance Company]. Available at: https://universalna.com/ru/

11.Pro strakhuvannya: Zakon Ukrayiny vid 07 bereznya 1996 roku № 85/96-VR (redaktsiya vid 01.08.2021, pidstava - 1591-IX). Available at: https://zakon.rada.gov.ua/laws/show/85/96-vr\#Text

12. Pro turyzm: Zakon Ukrayiny vid 15 veresnya 1995 roku № 324/95-VR (redaktsiya vid 16.10.2020, pidstava 124-IX). Available at: https://zakon.rada.gov.ua/laws/show/324/95-vr\#Text

13. Yarosh V. V. Perspektyvy rozvytku strakhuvannya turystiv v Ukrayini (2021) [Prospects for the development of tourist insurance in Ukraine]. Available at: https://conf.ztu.edu.ua/wp-content/uploads/2021/01/319.pdf 